\title{
Table Top Disaster Simulation to Enhance Community Knowledge of Flood Disaster Preparedness in Musi Rawas Regency
}

\author{
$1^{\text {st }}$ JhonFeri \\ Nursing Program \\ Health Polytechnic of Palembang \\ Lubuklinggau, Indonesia \\ jhonferi@poltekkespalembang.ac.id
}

\author{
$2^{\text {nd }}$ Susmini \\ Nursing Program \\ Health Polytechnic of Palembang \\ Lubuklinggau, Indonesia \\ susmini@poltekkespalembang.ac.id
}

\author{
$3^{\text {rd }}$ SapondraWIjaya \\ Nursing Program \\ Health Polytechnic of Palembang \\ Lubuklinggau, Indonesia \\ ondra@poltekkespalembang.ac.id
}

Corresponding author: ondra@ poltekkespalembang.ac.id

\begin{abstract}
As a high risk disasters country, Indonesia should have good strength in dealing with disasters, including community preparedness. The current condition of knowledge responding to disasters is not good. Continuous program are needed to prepare the community, One of the program is education and simulation. Table Top Disaster Simulation is one type of room simulation commonly used for a sequence of increasing community strength. This research aims was To determine the effect of the Table Top Disaster Simulation on the knowledge of MusiRawas community in responding the flood disaster The Methods was a Quantitative research with a quasi-experimental design with a pre and post test design approach. Data were collected using a questionnaire before and after the room simulation with the Table Top Disaster Simulation Model. Data were analyzed statistically by paired t- test. Result: This research covers 2 (two) Districts in MusiRawas Regency which every year floods occur with 100 sample. The t- test result is $p=0,000$ After being given education and room simulations using the Table Top Disaster Simulation Model there was an increase in knowledge about how people respond to a risk of disaster occurrence. This increase must be maintained so as not to decrease again
\end{abstract}

Keywords: Table Top Disaster Simulation, Disasters, Disaster Preparedness.

\section{INTRODUCTION}

The entire territory of Indonesia is a high risk to various kinds of disasters. All types of disasters exist in Indonesia so that our country is named "the super market of disasters". This situation makes Indonesia must be prepared to deal with disaster. Especially in South Sumatra, the most frequent disaster is looding.
MusiRawas Regency is one of the districts prone to natural disasters in the form of floods. Data from the community and Badan Penanggulangan Bencana Daerah (BPBD) [1] say that almost every year there are floods, landslides and forest fires. There are four districts that are at high risk of flooding, namely the districts of MuaraKelingi, MuaraLakit, MegangSakti and Bulang Tengah Suku Ulu.

Floods in MusiRawas Regency were caused by overflowing Musi and Kelingi rivers and also the home of residents in the watershed. On a massive scale, flooding will disrupt all activities of citizens, from government, economy and education paralyzed. It can even cause casualties if floods come suddenly. Minimizing the impact of disasters is the most important thing, including preparing human resources. Prevention, mitigation, and preparedness are three important factors that must be done so that the general public is better prepared to face the disaster [2].

Readiness is a major problem in disaster management, both logistical aspects and community aspects as the first responder in providing emergency response (Wijaya, et al [3]). Lack of knowledge about disaster response is one of the causes of nurses' inadequacy in disaster situations [4].

Readiness is crucial, including community preparedness in facing disasters in the emergency response phase. Having skilled skills as well as sufficient knowledge about disasters is one indicator that the community is ready to respond to the disaster and that can all be obtained through emergency response training whether or not there is a 
simulation and drill [5]. One form of community preparation is to provide education and training to the community on how to respond to disasters. Teach you the path in responding to disasters, starting from the moment of early warning to the stage of disaster emergency response even after the disaster. In the disaster response channel there is also a systematic communication flow so that the disaster response process runs well (Clerveaux, et al, [6]). One technique for giving material is to do a simulation, including simulation on a table or what is known as the "Table Top Simulation". Table Top Simulation is a meeting held to discuss an emergency simulation conducted in a room [7].

Pate, et al, [8] said there was an increase in knowledge, confidence, and understanding of the roles and responsibilities of students after being given training with the Table Top Simulation method. Table Top Simulation is very useful and effective as a teaching tool which can increase preparedness in responding to disasters [9]. [10] also said that after the simulation, there was an increase in the knowledge and response of civilian participants to disasters The purpose of this study was to determine the effect of the Table Top Disaster Simulation on the knowledge of the MusiRawas Regency community in responding to the flood disaster.

\section{METHOD}

This research was a quantitative study with a quasi experimental design with a pre and post test design approach. The population of this research was the communities in two high risk districts to flooding in the MusiRawas, Districts of MuaraKelingi and MuaraLakitan with a total of 773 people.

The sampling technique used was random sampling by applying a cluster sampling pattern (area sampling) that is taken in areas that were really affected by flooding in the two Districts with a sample of 100 people, 50 people in MuaraKelingi and 50 people in MuaraLakitan.

This research was conducted in November 2019. Data was collected using a questionnaire before and after disaster management education and simulation using the Table Top Disaster Simulation Model. Data were analyzed statistically using paired t-test.

\section{RESULT}

Table 1. Respondent Characteristics

\begin{tabular}{|c|c|c|c|c|c|}
\hline \multirow{2}{*}{\multicolumn{2}{|c|}{$\begin{array}{c}\text { Responden } \\
\text { Characteristics }\end{array}$}} & \multicolumn{2}{|c|}{$\begin{array}{l}\text { Kelingi } \\
\text { District } \\
\end{array}$} & \multicolumn{2}{|c|}{$\begin{array}{l}\text { Lakitan } \\
\text { District } \\
\end{array}$} \\
\hline & & Freq & $\%$ & Freq & $\%$ \\
\hline \multirow{4}{*}{ Age } & 21-30 Age & 6 & $12 \%$ & 10 & $20 \%$ \\
\hline & $31-40$ Age & 23 & $46 \%$ & 24 & $48 \%$ \\
\hline & 41-50 Age & 17 & $34 \%$ & 13 & $26 \%$ \\
\hline & 51-60 Age & 4 & $8 \%$ & 3 & $6 \%$ \\
\hline \multirow{2}{*}{ Gender } & Male & 19 & $38 \%$ & 25 & $50 \%$ \\
\hline & Female & 31 & $62 \%$ & 25 & $50 \%$ \\
\hline \multirow{5}{*}{ Education } & $\begin{array}{c}\text { Elementary } \\
\text { School }\end{array}$ & 1 & $2 \%$ & 12 & $24 \%$ \\
\hline & $\begin{array}{l}\text { Middle } \\
\text { School }\end{array}$ & 14 & $28 \%$ & 28 & $56 \%$ \\
\hline & High School & 28 & $56 \%$ & 7 & $14 \%$ \\
\hline & Diploma & 6 & $12 \%$ & 2 & $4 \%$ \\
\hline & Bachelor & 1 & $2 \%$ & 1 & $2 \%$ \\
\hline
\end{tabular}

Table 1 shows the characteristics of the respondents of this study, an average of $90 \%$ of participants in each district with education levels up to senior high below. The data above also shows that an average of $92 \%$ in each participating district is a maximum of 40 years.

Table 2. Average Knowledge Value Results

\begin{tabular}{lccc}
\hline \multicolumn{1}{c}{ Variable } & & $\begin{array}{c}\text { Kelingi } \\
\text { District }\end{array}$ & $\begin{array}{l}\text { Lakitan } \\
\text { District }\end{array}$ \\
\hline \multirow{2}{*}{ Knowledge } & Pre & 56.27 & 60.00 \\
\cline { 2 - 4 } & Post & 74.00 & 75.87 \\
\hline
\end{tabular}

Table 2 shows that there was an increase in the average value of knowledge before and after the intervention in the two study areas.

Table 3. Paired t-Test Results

\begin{tabular}{ccccc}
\hline & & & \\
\cline { 2 - 3 } Variable & Kelingi & t & & p-value \\
\hline \multirow{2}{*}{ Knowledge } & Area & & -12.486 & 0.000 \\
\hline & Lakitan Area & -15.238 & 0.000 \\
\hline
\end{tabular}

Table 3 shows that the p-value of knowledge before and after the intervention is 0.000 , which means significant.

The analysis of knowledge of community before and after simulation were increase which similar with the theory that the purpose of health education is the occurrence of changes in knowledge, attitudes and behavior of individuals, families, special groups, and society [11]. 
The purpose of an education is to change or improve feelings with actions that can be done, namely playing roles, direct experience, discussion, giving examples or models [12]. These objectives can be proven by the results of this study, namely there was an increase in public knowledge about disaster management. The change in community knowledge above occurred after the education and training in room simulation using the Table Top Disaster Simulation method. The use of this room simulation method based on facts in the field is very effective in preparedness in responding to disasters [13].

The use of this method is not a single method but is a sequence of mitigation activities to strengthen communities in responding to disasters which end with a field simulation method.

Based on statistical test data, there was a significant influence in the implementation of education and field simulation of table top disaster simulation method to the knowledge of the community in responding to flood disasters with a value of p 0,000. Pate, et al, [14] said there was an increase in knowledge, confidence, and understanding of the roles and responsibilities of students after being given training with the Table Top Simulation method.

All subject were civil society with average $90 \%$ of their education were high school or below. The data above shows that this room simulation with Table Top Simulation Models is very simple and very easy for people to understand. $63 \%$ of subject were below 40 years old, the data show that our purpose to strengthen the community was in line with the subject. Where in that age people become the main people in the community.

The main purpose of this space simulation is to help organizations test their ability to deal with certain incidents, evaluate the ability and readiness of certain groups to work together and respond to emergencies, and discuss the roles, responsibilities and anticipated activities, including plans, policies, and procedures . Perry[15] also said that after the simulation, there was an increase in the knowledge and response of civilian participants to disasters.

\section{CONCLUSION}

As a high risk disasters country, Indonesia should have good strength in dealing with disasters, including community preparedness. One of the solution is a Table Top Disaster Simulation. After being given education and room simulations using the Table Top
Disaster Simulation Model there was an increase in knowledge about how people respond to a risk of disaster occurrence.

\section{ACKNOWLEDGMENT}

The author is grateful to the Health Polytechnic of Palembang for assisting in funding this research scheme. The Author also thank you to MusiRawas Government and BPBD MusiRawas for assisting in Data Collect.

\section{REFERENCES}

[1] Setio Galih Marlyono, 2016 Pengaruh Literasi Informasi Bencana Terhadap Kesiapsiagaan Masyarakat Di Alam Menghad Api Bencana di Provinsi Jawa Barat Universitas Pendidikan Indonesia | repository.upi.edu perpustakaan.upi.edu 2016:147-54.

[2] Wijaya S, Andarini S, Setyoadi. Survivor Pertolongan Kesehatan Saat Respon Tanggap Darurat Pada Korban Bencana Tsunami Tahun 2004 Di Lhoknga Dan Lhoong. J Kesehat Wiraraja Med 2005:108-17.

[3] BadanNasionalPenanggulanganBencana. No Title. Jakarta: 2012.

[4] Chapman K, Arbon P. Are nurses ready?. Disaster preparedness in the acute setting. Australas Emerg Nurs J 2008;11:135-44. https://doi.org/10.1016/j.aenj.2008.04.002.

[5] Doherty GW. Crisis Intervention Training for Disaster Workers: An introduction. Rocky Mt Reg Disaster Ment Heal Inst 2006.

[6] Coppola D. No Title. 2011.

[7] Lerveaux VC, Atada TK, Osoi KH. Information Simulation Model: Effective Risk Communication and. J Nat Disaster Sci 2008;30:1-11.

[8] Geller E. No Title. 2000.

[9] Szpytek S, Safety L. Emergency Preparedness and Tabletop Exercise (TTX) 2017:1-49.

[10] Hammad KS, Arbon P, Gebbie KM. Emergency nurses and disaster response: An exploration of South Australian emergency nurses' knowledge and perceptions of their roles in disaster response. Australas Emerg Nurs J 2011;14:87-94. https://doi.org/10.1016/j.aenj.2010.10.002.

[11] Hammad KS, Arbon P, Gebbie K, Hutton A. Nursing in the emergency department (ED) during a disaster: A review of the current literature. Australas Emerg Nurs J
2012;15:235-44. https://doi.org/10.1016/j.aenj.2012.10.005.

[12] Johnstone M, D P, Turale S. Nurses ' experiences of ethical preparedness for public health emergencies and healthcare disasters : A systematic review of qualitative evidence 2014:67-77. https://doi.org/10.1111/nhs.12130.

[13] Khankeh HR. Ar c hi ve of Ar c of n.d.;27:35-43.

[14] Evans CA, Bc N. Tabletop exercises in the nursing classroom: An introduction for nurse educators. Nurs Forum 2019:1-6. https://doi.org/10.1111/nuf.12394. 